\title{
Vascular endothelial growth factor as a potential prognosticator in Ewing Sarcoma: a tertiary care cancer center experience from India
}

\author{
Jyoti Bajpai ${ }^{1}$, Goutam Panda ${ }^{2}$, Madala Ravikrishna ${ }^{2}$, Arun Chandrasekharan ${ }^{3}$, Bharat \\ Rekhi $^{3}$, Prabhat Bhargava ${ }^{2}$, Sujay Srinivas ${ }^{2}$, Siddhartha Laskar ${ }^{3}$, Smruti Mokal ${ }^{2}$, Nehal \\ Khanna $^{3}$, Vijay Patil ${ }^{2}$, Vanita Noronha ${ }^{2}$, Amit Joshi² ${ }^{2}$ Kumar Prabhash ${ }^{2}$, Sripad \\ Banavali $^{2}$, and Sudeep Gupta ${ }^{3}$
}

\author{
${ }^{1}$ AIIMS \\ ${ }^{2}$ Tata Memorial Centre \\ ${ }^{3}$ Tata Memorial Hospital
}

February 18, 2022

\begin{abstract}
Introduction: Vascular endothelial growth factor (VEGF)is an angiogenic marker and implicated in carcinogenesis and prognostication of cancers. However its prognostic potential in a rare cancer-Ewing's sarcoma merits exploration. Methods: Histopathologically confirmed consecutive ES cases registered at our institute from 2014 to 2018 were analysed. Immunohistochemical staining for VEGF was performed on tumour tissues and they were further classified based on VEGF intensity. Results: There were 105 patients including 53 non-metastatic and 52 metastatic. VEGF immunostaining in non-metastatic and metastatic cohort was negative in $20(37.7 \%)$ and $21(40.4 \%)$, mildly positive in $13(24.5 \%)$ and $9(17.3 \%)$ cases, moderately positive in 14 $(26.4 \%)$ and $16(30.8 \%)$, and was intensely positive in $6(11.3 \%)$ and $7(13.5 \%)$ patients, respectively. VEGF immunoexpression up to $25 \%$ was seen in $14(13.3 \%)$ and $10(9.5 \%)$ patients within the non-metastatic and metastatic cohort, respectively. The median EFS and OS for the entire cohort were 26.4 (95\% CI 17.6-NA) and 32.5 (21.3-NA) months, respectively. Metaststatic ES patients having either VEGF immunostaining in $>25 \%$ tumor cells or moderate /strong immunostaining were found to inferior EFS and OS $[\mathrm{p}=0.017$, HR-0.153; $\mathrm{p}=0.013$, HR-0.109 respectively].Additionally, treatment-naïve, compliant and non-metastatic patients had superior EFS $(\mathrm{p}=0.000,0.000,0.020,0.022$ respectively) and $\mathrm{OS}(\mathrm{p}=0.000,0.000,0.006,0.041$ respectively). Conclusion: VEGF expression and intensity were found as independent negative prognostic marker in Ewing sarcoma . This may translate to therapeutic relevance but needs validation in the subsequent, larger prospective studies.
\end{abstract}

\section{Hosted file}

Title page_abstract_Manuscript_VEGF in ES.docx available at https://authorea.com/users/ 395932/articles/556975-vascular-endothelial-growth-factor-as-a-potential-prognosticatorin-ewing-sarcoma-a-tertiary-care-cancer-center-experience-from-india

\section{Hosted file}

Table 1.docx available at https://authorea.com/users/395932/articles/556975-vascularendothelial-growth-factor-as-a-potential-prognosticator-in-ewing-sarcoma-a-tertiarycare-cancer-center-experience-from-india

\section{Hosted file}

Table 2.docx available at https://authorea.com/users/395932/articles/556975-vascularendothelial-growth-factor-as-a-potential-prognosticator-in-ewing-sarcoma-a-tertiarycare-cancer-center-experience-from-india 


\section{Hosted file}

Table 3.docx available at https://authorea.com/users/395932/articles/556975-vascularendothelial-growth-factor-as-a-potential-prognosticator-in-ewing-sarcoma-a-tertiarycare-cancer-center-experience-from-india

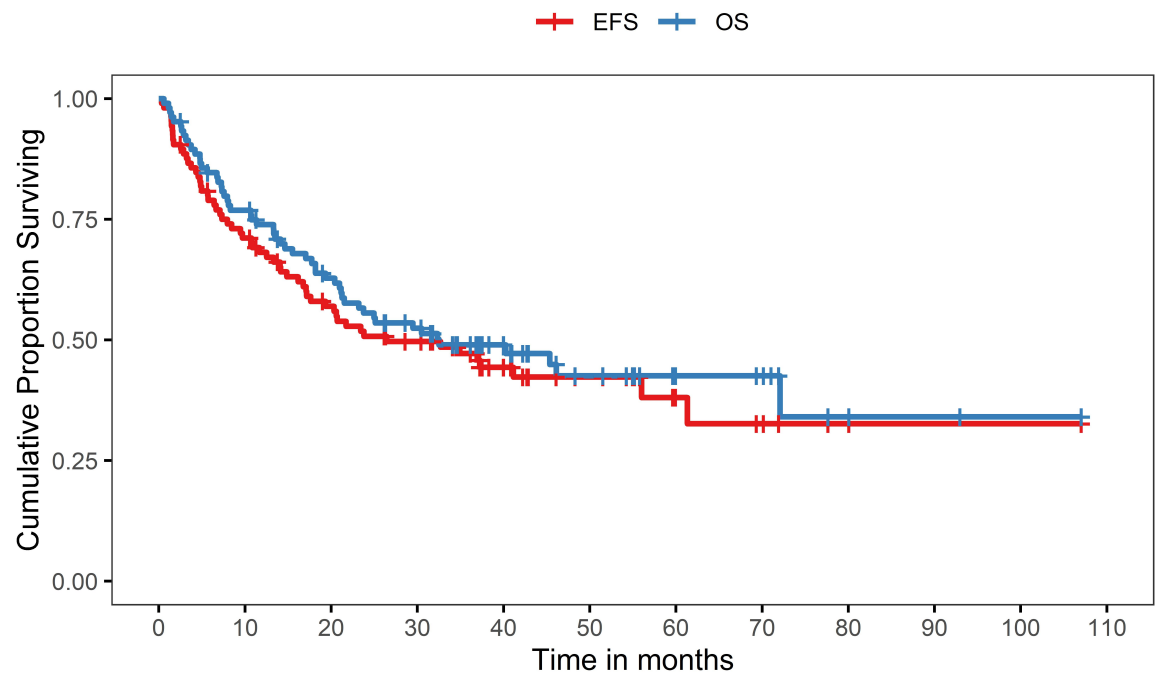

Number at risk

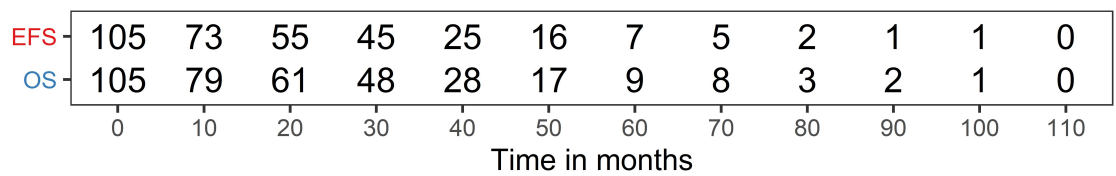

